\title{
Murinometric measurements and retroperitoneal adipose tissue in young rats exposed to the high-fat diet: Is there correlation?
}

\author{
A. P. A Macêdo * (D), G. S. Cordeiro ${ }^{b}$ (D), L. S. Santos ${ }^{b}$ (D), D. A. E. Santo (D), G. S. Perez $^{b}$ (D), \\ R. D. Couto $^{a, c}$ (D) M. E. P. C. Machado ${ }^{b, d}$ (D) J. M. Barreto Medeiros ${ }^{b, d}$
}

aPrograma de Pós-Graduação em Ciências de Alimentos, Faculdade de Farmácia, Universidade Federal da Bahia, Rua Barão de Jeremoabo, s/n, Ondina, Código Postal 41170-290, Salvador, BA, Brasil

bPrograma de Pós-Graduação em Alimento, Nutrição e Saúde, Escola de Nutrição, Universidade Federal da Bahia, Avenida Araújo Pinho, 32, Canela, Código Postal 40110-150, Salvador, BA, Brasil.

'Departamento de Análises Clínicas e Toxicológicas, Faculdade de Farmácia, Universidade Federal da Bahia, Rua Barão de Jeremoabo, s/n, Ondina, Código Postal 41170-290, Salvador, BA, Brasil.

${ }^{d}$ Departamento de Ciências da Nutrição, Escola de Nutrição, Universidade Federal da Bahia, Avenida Araújo Pinho, 32, Canela, Código Postal 40110-150, Salvador, BA, Brasil.

*e-mail: paulamacedo.nut@gmail.com

Received: March 18, 2019 - Accepted: November 16, 2019 - Distributed: May 31, 2021

\begin{abstract}
Aim: This study aimed to verify the correlation between murine measurements and retroperitoneal adipose tissue in rats exposed to the high-fat diet. Material and methods: Wistar male adult rats, descendants of mothers who consumed a high-fat diet during pregnancy and lactation and fed the same diet after weaning were used. At 60 days of life, body weight, longitudinal axis and waist circumference (WC) were measured. The Body Mass Index (BMI) and the Lee Index were calculated for a posterior analysis of the correlation with the amount of retroperitoneal adipose tissue dissected on the same day. For analysis of the data, the Pearson correlation test was used, considering statistical significance for $\mathrm{p}<0.05$. Results: Body weight had a weak correlation $(\mathrm{r}=0.31 ; \mathrm{p}=0.38)$ with retroperitoneal adipose tissue. While the longitudinal correlated moderately and negative $(r=-0.40 ; p=0.25)$. Abdominal circumference $(r=0.62 ; p=0.05)$, body mass index $(r=0.61 ; p=0.03)$ and Lee $(r=0.69 ; \mathrm{p}=0.03)$ correlated moderately and positively with adipose tissue. Conclusion: Among the measured murine measurements, weight and longitudinal axis were not good indicators to represent accumulation of retroperitoneal adipose tissue in rats. However, Lee's index seems to be the best murine marker to diagnose the accumulation of retroperitoneal fat. BMI, CA and Lee index were murine parameters with higher correlation.
\end{abstract}

Keywords: high-fat diet, obesity, rats, murinometric index, retroperitoneal adipose tissue.

\section{Medidas murinométricas e tecido adiposo retroperitoneal em ratos jovens expostos à dieta hiperlipídica: existe correlação?}

\begin{abstract}
Resumo
Objetivo: Este estudo teve como objetivo verificar a correlação entre medidas murinométricas e tecido adiposo retroperitoneal em ratos expostos à dieta hiperlipídica. Material e métodos: Foram utilizados ratos Wistar machos adultos, descendentes de mães que consumiram dieta hiperlipídica durante a gestação e lactação e alimentados com a mesma dieta após o desmame. Aos 60 dias de vida, foram medidos o peso corporal, o eixo longitudinal e a circunferência da cintura (CC). O Índice de Massa Corporal (IMC) e o Índice de Lee foram calculados para posterior análise da correlação com a quantidade de tecido adiposo retroperitoneal dissecado no mesmo dia. Para análise dos dados, utilizou-se o teste de correlação de Pearson, considerando significância estatística para $\mathrm{p}<0.05$. Resultados: O peso corporal apresentou uma correlação fraca $(r=0,31 ; \mathrm{p}=0,38)$ com o tecido adiposo retroperitoneal. Enquanto o longitudinal correlacionou moderadamente e negativo $(r=-0,40 ; p=0,25)$. A circunferência abdominal $(r=0,62 ; p=0,05)$, índice de massa corporal $(\mathrm{r}=0,61 ; \mathrm{p}=0,03)$ e Lee $(\mathrm{r}=0,69 ; \mathrm{p}=0,03)$ correlacionaram-se moderada e positivamente com o tecido adiposo. Conclusão: Entre as medidas murinométricas, o peso e o eixo longitudinal não foram bons indicadores para representar o acúmulo de tecido adiposo retroperitoneal em ratos. No entanto, o índice de Lee parece ser o melhor indicador murinométrico para diagnosticar o acúmulo de gordura retroperitoneal. O IMC, índice de Lee e CA foram parâmetros murinométricos com maior correlação.
\end{abstract}

Palavras-chave: dieta hiperlipídica, obesidade, ratos, índice murinométrico, tecido adiposo retroperitoneal. 


\section{Introduction}

Obesity is considered a public health problem due to the high prevalence and its comorbidities (Banik and Rahman, 2018; Luz et al., 2017). The accumulation of fat in the abdominal region has been reported as a determining factor for the development of chronic non-transmissible diseases (Almeida et al., 2016).

The increasing number of obese individuals is associated with excessive consumption of high-calorie and high-fat diets, especially saturated fats (Nasreddine et al., 2018). Animal scientific research has sought to reproduce the human dietary habit using high-fat diets, inducing the accumulation of body fat, to similarly reflect the metabolic alterations found in human obesity (West and York, 1998; Casper et al., 2008).

It is well established in the literature that the ingestion of hypercaloric and high-fat diets are directly related to the development of obesity in rodents (Souza et al., 2018; Lima et al., 2018). Thus, in recent years, health professionals and researchers in the field have developed experimental studies to understand this clinical condition (Mittwede et al., 2016).

In experimental studies with rodents exposed to the high-fat diet the murinometric parameters such as body weight, longitudinal axis, and circumference of the abdomen (CA) have been used extensively; and Lee and body mass indexes (BMI) to identify adiposity and diagnose obesity (Licholai et al., 2018; Mcnay and Speakman, 2013). However, it is known that the measurement of body fat is the most sensitive indicator to diagnose obesity (Hariri and Thibault, 2010).

Despite its accuracy, analyzing adipose tissue is a difficult and costly method when compared to basic murine measurements, which makes it usual to measure these measurements in most of the work in rats. Thus, it is relevant to evaluate whether there is a correlation between the murine metric indicators and the amount of retroperitoneal adipose tissue. Therefore, the purpose of this study is to verify the correlation between murine measurements and retroperitoneal adipose tissue in high-fat diet exposed rats.

\section{Material and Methods}

This study was approved by the Ethics Committee on Animal Experimentation, Faculty of Veterinary Medicine and Animal Science, UFBA, according to protocol n 59/2017. Young rats (Rattus norvegicus), of the Albinus variety, of the Wistar strain at the Laboratory of Experimental Nutrition of the Federal University of Bahia (UFBA), were carried out, in which all animals were kept under the same conditions, with a temperature of $23 \pm 2{ }^{\circ} \mathrm{C}$ and light / dark cycle of 12 hours.

\subsection{Experimental design}

The animals were from primiparous females fed with high-fat during pregnancy and lactation. Wistar rats were used between 90 and 100 days, with a minimum body weight of $220 \mathrm{~g}$ and a maximum of $280 \mathrm{~g}$.

The onset of gestation was confirmed by the vaginal smear test (Perez et al., 2015). On the first day of gestation, it was offered to the fat high diet $(n=4)$. The females maintained the consumption of the high-fat diet until the end of the lactation (21st day of life of the descendants). After weaning, which occurred on the $22^{\text {nd }}$ day of life of the offspring, the high-fat diet was offered to the offspring $(n=10)$ until the sixtieth day of life of the animal.

\subsection{High-fat diet}

This diet consisting of a mixture of commercial ration (Nuvilab ${ }^{\circledR}$ CR1) with roasted peanuts, milk chocolate, and Maria type biscuit, in a ratio of 3: 2: 2: 1 . These ingredients were milled, mixed and heated in an oven at $60{ }^{\circ} \mathrm{C}$. Subsequently, they were offered in the form of pellets, containing the percentage of lipids of $23 \%$ (Oliveira et al., 2011).

\subsection{Data collect}

On the sixtieth day of life of the offspring, measurements were measured as: weight, longitudinal axis, abdominal circumference and weight of retroperitoneal adipose tissue. And then calculated the BMI, the Lee Index.

The animals' body weight was recorded using a digital electronic scale -Mart, model S-4000, with a capacity of $4 \mathrm{~kg}$ and a sensitivity of $0.001 \mathrm{~g}$. Body length was assessed by measuring the longitudinal axis of the naso-anal. With the aid of a pen, the points between the muzzle and the base of the tail were marked, and the distance between them was evaluated by a digital caliper of 0.01 (BTS digital caliper) accuracy. The abdominal circumference was determined by the circumference of the midpoint between the anterior and posterior legs, a method used by Pini et al. (2016).

BMI was determined by body weight $(\mathrm{g}) /$ length $^{2}(\mathrm{~cm})$ (Novelli et al., 2007) and for the Lee Index, proposed by Lee in 1928, the formula consists of dividing the cubic root weight in grams by the naso-anal length in centimeters (Bernardis and Patterson, 1968).

For the collection of retroperitoneal adipose tissue, the adipose tissue was dissected, sterilized in saline and heavy.

\subsection{Statistical analysis}

For analysis of the correlation of the murinometric indicators with retroperitoneal adipose tissue, we used the Pearson correlation test, considering the following classification: weak $(0<\mathrm{r}<0.4)$; moderate $(0.4 \leq \mathrm{r}<0.7)$ and strong $(r \geq 0.7)$. Correlations with statistical significance were considered those with a moderate or strong correlation degree and $\mathrm{p} \leq 0.05$ (Siqueira and Tibúrcio, 2011).

\section{Results}

The descriptive analysis of the murine parameters and the amount of retroperitoneal adipose tissue of the high-fat offspring on the sixtieth day of life is shown in Table 1. The body weight presented a weak correlation $(r=0.31$, $\mathrm{p}=0.38$ ), while the longitudinal correlated moderately 
Table 1. Murine measurements and amount of retroperitoneal adipose tissue in young rats submitted to the high-fat diet.

\begin{tabular}{lcrr}
\hline & N & Mean & Standard deviation \\
\hline Weight $(\mathbf{g})$ & 10 & 199.52 & 12.54 \\
Longitudinal axis (cm) & 10 & 20.34 & 0.57 \\
Abdominal Circumference (cm) & 10 & 14.81 & 0.59 \\
Body Mass Index $\left(\mathbf{g . c m}^{-2}\right)$ & 10 & 0.48 & 0.03 \\
Lee Index $\left(\sqrt[3]{\text { g.cm }^{-1}}\right)$ & 10 & 0.29 & 0.01 \\
Retroperitoneal adipose tissue (g) & 10 & 4.50 & 0.95 \\
\hline
\end{tabular}

Table 2. Correlation coefficient between the murinometric indicators and the amount of retroperitoneal adipose tissue in young rats submitted to the high-fat diet.

\begin{tabular}{|c|c|c|}
\hline & $\mathbf{r}$ & p-value \\
\hline Weight (g) & 0.31 & 0.38 \\
\hline Longitudinal axis (cm) & -0.40 & 0.25 \\
\hline Abdominal Circumference $(\mathrm{cm})$ & 0.62 & 0.05 \\
\hline Body Mass Index (g.cm²) & 0.61 & 0.06 \\
\hline Lee Index $\left(\sqrt[3]{\text { g.cm }^{-1}}\right)$ & $0.69 *$ & 0.03 \\
\hline
\end{tabular}

* Statistically significant correlation, $\mathrm{p}<0.05$.

and negative $(\mathrm{r}=-0.40, \mathrm{p}=0.25)$ with the amount of retroperitoneal adipose tissue. Abdominal circumference $(\mathrm{r}=0.62, \mathrm{p}=0.05)$, body mass index $(\mathrm{r}=0.61, \mathrm{p}=0.03)$ and Lee $(r=0.69, p=0.03)$ correlated moderately and positively with adipose tissue. Only Lee's index showed a statistically significant correlation (Table 2).

\section{Discussion}

In the present study, the high-fat diet-induced accumulation of retroperitoneal adipose tissue in rats and the correlation with the commonly used murine measurements was used to diagnose obesity. Among the measured murine measurements, BMI, CA and Lee index were murine parameters with a higher correlation. However, weight and longitudinal axis were not good indicators to represent the accumulation of retroperitoneal adipose tissue in rats. The consumption of foods high in fat and high energy density has increased worldwide (Kratz et al., 2013; Santos et al., 2019). This excessive intake causes an increase in body adiposity and has a strong association with chronic non-transmissible diseases (Kratz et al., 2013).

According to the results found in this study, the weak correlation of body weight with retroperitoneal adipose tissue, without statistical significance. May be related to the fact that weight does not evaluate body composition (Gerbaix et al., 2010). Considering that body weight is determined by bone, muscle and adipose tissues, it may be that changes in the amount of bone and muscle tissues have influenced the results found. Corroborating with the findings in this study, Lac et al. (2008), rodents fed a high-fat diet in adulthood showed lower levels of bone minerals, bone mineral density, and skeletal area. Similarly, Pomar et al. (2017), the offspring of rats fed a diet with high lipid content during lactation had lower body weight and lower lean mass, but a greater amount of adipose tissue.
Obesity causes chronic inflammation that can affect the integrity and function of tissues. In muscle tissue, there is a greater deposition of adipose tissue. This promotes specific changes in the metabolism of muscle proteins, impairing protein synthesis in the muscle (Tardif et al., 2014; Collins et al., 2016). This mechanism justifies the possible loss of lean mass in the animals studied, and, consequently, the loss of weight.

The studies that investigated, the longitudinal axis, another murinometric parameter, are few. It is mainly measured to perform the calculation of BMI and the Lee index (Sospedra et al., 2015). The results of this analysis showed a moderate and negative correlation with adipose tissue, without statistical significance. It may be that the longitudinal growth of the animal has contributed to a greater distribution of body fat (Nascimento et al., 2008).

In the present study, a moderate correlation was found between the abdominal circumference and adipose tissue, but no statistical significance. suggesting that this is a good parameter to evaluate the accumulation of retroperitoneal fat. Simillary, Angéloco et al. (2012) identified a moderate and positive correlation for abdominal circumference with carcass fat in rodents submitted to a high-fat or highsucrose diet. Differently, Gerbaix et al. (2010) considered abdominal circumference as a useful tool after having correlated strongly and significantly with the amount of adipose tissue evaluated by radiographic dual-energy absorptiometry (DEXA) and by dissection of the perirenal and peri-epididymal tissues.

Regarding BMI, a moderate and positive correlation was evidenced, with no statistical significance. It is important to consider, during the BMI analysis, that this indicator was formulated to assess the nutritional status of humans (Dutra et al. 2018). With this in mind, great care must be taken in adapting this parameter to animals. In agreement with the results of this work, Angéloco et al. (2012) observed 
a strong and positive correlation. However, in the work of Novelli et al. (2007), the result of the classification obtained in his study was a very strong correlation. This difference in the intensity of classification can be attributed to the fact that the researchers used a different classification for the correlation values and because they evaluated the carcass fat. And BMI accurately comprises calculating body mass, not retroperitoneal mass.

Contrary to body mass index, the Lee index was developed specifically for rats to evaluate obesity in these animals (Bernardis and Patterson, 1968). As the Lee index is a specific indicator for rats, this specificity may have resulted in a moderate correlation with statistically significant found with the amount of adipose tissue. Angelóco et al. (2012) showed a positive and strong correlation between the Lee index and carcass fat, suggesting that the Lee index is a good indicator to evaluate body fatness. The difference in the intensity of the classification, as well as the BMI, is because Angelóco et al. (2012) analyzed the total fat of the carcass of the animal.

\section{Conclusion}

The high-fat diet was able to promote the accumulation of retroperitoneal fat in animals exposed to the diet until adult life. Considering the results of the present study, it can be concluded that the weight and the longitudinal axis did not present a good correlation with retroperitoneal adipose tissue in young rats, but the BMI, CA and the Lee index were murine parameters with higher correlation. Lee's index seems to be the best murine marker to diagnose retroperitoneal fat accumulation. Therefore, scientific research using rodents to simulate human obesity should investigate the murine measurements more carefully and associate these with other indicators to ensure the reliability of the results reported.

\section{Acknowledgements}

To the Foundation for Research Support of the State of Bahia (FAPESB), the Coordination of Improvement of Higher Education Personnel (CAPES) and the National Research Council (CNPq) for financial support.

\section{References}

ALMEIDA, J.B., KIAN, K.O., LIMA, R.C. and SOUZA, M.C.C., 2016. Total and abdominal adiposity and hypertension in indigenous women in Midwest Brazil. PLoS One, vol. 11, no. 6, pp. 1-20. http://dx.doi.org/10.1371/journal.pone.0155528. PMid:27294870.

ANGÉLOCO, L.R.N., DEMINICE, R., LEME, I.A., LATARO, R.C. and JORDÃO, A.A., 2012. Bioelectrical impedance analysis and anthropometry for the determination of body composition in rats: effects of high-fat and high-sucrose diets. Revista de Nutrição, vol. 25, no. 3, pp. 331-339. http://dx.doi.org/10.1590/ S1415-52732012000300003.

BANIK, S. and RAHMAN, M., 2018. Prevalence of overweight and obesity in Bangladesh: A systematic review of the literature.
Current Obesity Reports, vol. 7, no. 4, pp. 1-7. http://dx.doi. org/10.1007/s13679-018-0323-x. PMid:30349968.

BERNARDIS, L. L. and PATTERSON B. D. 1968, Correlation between 'Lee index' and carcass fat content in weanling and adult female rats with hypothalamic lesions. Journal of Endocrinology, vol. 40, no. 4, pp. 527-528. https://doi.org/10.1677/joe.0.0400527

CASPER, R.C., SULLIVAN, E.L. and TECOTT, L., 2008. Relevance of animal models to human eating disorders and obesity. Psychopharmacology, vol. 199, no. 3, pp. 313-329. http://dx.doi. org/10.1007/s00213-008-1102-2. PMid:18317734.

COLLINS, K.H., HART, D.A., REIMER, R.A., SEERATTAN, R.A., WATERS-BANKER, C., SIBOLE, S.C. and HERZOG, W., 2016. High-fat high-sucrose diet leads to dynamic structural and inflammatory alterations in the rat vastus lateralis muscle. Journal of Orthopaedic Research, vol. 34, no. 12, pp. 2069-2078. http:// dx.doi.org/10.1002/jor.23230. PMid:26990324.

DUTRA, M.T., MARTINS, K.G., VIEIRA, D.D.R., OLIVEIRA, A.S. and MOTA, M.R., 2018. Association between adiposity indices and blood pressure is stronger in sarcopenic obese women. Current Hypertension Reviews, vol. 14, no. 1. http://dx.doi.org/1 0.2174/1573402114666181031145341. PMid:30381084.

GERBAIX, M., METZ, L., RINGOT, E. and COURTEIX, D., 2010. Visceral fat mass determination in rodent: validation of dual-energy X-ray absorptiometry and anthropometric techniques in fat and lean rats. Lipids in Health and Disease, vol. 9, no. 1, pp. 140. http://dx.doi.org/10.1186/1476-511X-9-140. PMid:21143884.

HARIRI, N. and THIBAULT, L., 2010. High-fat diet-induced obesity in animal models. Nutrition Research Reviews, vol. 23, no. 2, pp. 270-299. http://dx.doi.org/10.1017/S0954422410000168. PMid:20977819.

KRATZ, M., BAARS, T. and GUYENET, S., 2013. The relationship between high-fat dairy consumption and obesity, cardiovascular, and metabolic disease. European Journal of Nutrition, vol. 52, no. 1, pp. 1-24. http://dx.doi.org/10.1007/s00394-012-0418-1. PMid:22810464.

LAC, G., CAVALIE, H., EBAL, E. and MICHAUX, O., 2008. Effects of a high fat diet on bone of growing rats. Correlations between visceral fat, adiponectin and bone mass density. Lipids in Health and Disease, vol. 7, no. 1, pp. 16. http://dx.doi. org/10.1186/1476-511X-7-16. PMid:18442361.

LICHOLAI, J.A., NGUYEN, K.P., FOBBS, W.C., SCHUSTER, C.J., ALI, M.A. and KRAVITZ, A.V., 2018. Why do mice overeat high-fat diets? how high-fat diet alters the regulation of daily caloric intake in mice. Obesity, vol. 26, no. 6, pp. 1026-1033. http://dx.doi.org/10.1002/oby.22195. PMid:29707908.

LIMA, M.S., PEREZ, G.S., MORAIS, G.L., SANTOS, L.S., CORDEIRO, G.S., COUTO, R.D., DEIRÓ, T.C.B.J., LEANDRO, C.G. and BARRETO-MEDEIROS, J.M., 2018. Effects of maternal high fat intake during pregnancy and lactation on total cholesterol and adipose tissue in neonatal rats. Brazilian Journal of Biology = Revista Brasileira de Biologia, vol. 78, no. 4, pp. 615-618. http://dx.doi.org/10.1590/1519-6984.166788. PMid:29319751.

LUZ, F. Q, SAINSBURY, A., MANNAN H., TOUYZ, S., MITCHISON,D. and HAY, P., 2017. Prevalence of obesity and comorbid eating disorder behaviors in South Australia from 1995 to 2015. International Journal of Obesity, vol. 41, pp. 1148-1153. http://dx.doi.org/10.1038/ijo.2017.79. PMid:28337025.

MCNAY, D.E.G. and SPEAKMAN, J.R., 2013. High fat diet causes rebound weight gain. Molecular Metabolism, vol. 2, no. 
2, pp. 103-108. http://dx.doi.org/10.1016/j.molmet.2012.10.003. PMid:24199147.

MITTWEDE, P.N., CLEMMER, J.S., BERGIN, P.F. and XIANG, L., 2016. Obesity and critical illness: insights from animal models. Shock, vol. 45, no. 4, pp. 349-358. https://dx.doi.org/10.1097\%2 FSHK.0000000000000512

NASCIMENTO, A.F., SUGIZAKI, M.M., LEOPOLDO, A.S., LIMA-LEOPOLDO, A.P., NOGUEIRA, C.R., NOVELLI, E.L., PADOVANI, C.R. and CICOGNA, A.C., 2008. Misclassification probability as obese or lean in hypercaloric and normocaloric diet. Biological Research, vol. 41, no. 3, pp. 253-259. http:// dx.doi.org/10.4067/S0716-97602008000300002. PMid:19399338.

NASREDDINE, L.M., KASSIS, A.N., AYOUB, J.J., NAJA, F.A. and HWALLA, N.C., 2018. Nutritional status and dietary intakes of children amid the nutrition transition: the case of the Eastern Mediterranean Region. Nutrition Research, vol. 57, pp. 12-27. http://dx.doi.org/10.1016/j.nutres.2018.04.016.

NOVELLI, E.L.B., DINIZ, S., GALHARDI, C.M., EBAID, G.M.X., RODRIGUES, H.G., MANI, F., FERNANDES, A.A., CICOGNA, A.C. and NOVELLI FILHO, J.L., 2007. Anthropometrical parameters and markers of obesity in rats. Laboratory Animals, vol. 41, no. 1, pp. 111-119. http://dx.doi. org/10.1258/002367707779399518. PMid:17234057.

OLIVEIRA, T.W.S., LEANDRO, C.G., JESUS DEIRÓ, T.C.B., PEREZ, G.S., SILVA, D.F., DRUZIAN, J.I., COUTO, R.D. and BARRETO-MEDEIROS, J.M., 2011. A perinatal palatable highfat diet increases food intake and promotes hypercholesterolemia in adult rats. Lipids, vol. 46, no. 11, pp. 1071-1074. http://dx.doi. org/10.1007/s11745-011-3604-7. PMid:21847693.

PÉREZ, G.S., SANTOS, L.S., CORDEIRO, G.S., PARAGUASSÚ, G.M., ATHANAZIO, D.A., COUTO, R.D., DEIRÓ, T.C.B.J., CASTRO, R.M. and BARRETO-MEDEIROS, J.M., 2015. Maternal and postweaning exposure to a high fat diet promotes visceral obesity and hepatic steatosis in adult rats. Nutrición Hospitalaria, vol. 32, no. 4, pp. 1653-1658. http://dx.doi. org/10.3305/nh.2015.32.4.9607. PMid:26545531.

PINI, R.T.B., VALES, L.D.M.F., COSTA, T.M.B.C. and ALMEIDA, S.S., 2016. Effects of cafeteria diet and high fat diet intake on anxiety, learning and memory in adult male rats. Nutritional Neuroscience, vol. 20, no. 7, pp. 396-408. http://dx.doi.org/10.1 080/1028415X.2016.1149294. PMid:28277186.
POMAR, C.A., VAN NES, R., SÁNCHEZ, J., PICÓ, C., KEIJER, J. and PALOU, A, 2017. Maternal consumption of a cafeteria diet during lactation in rats leads the offspring to a thin-outsidefat-inside phenotype. International Journal of Obesity, vol. 41, no. 8, pp. 1279-2017. http://dx.doi.org/10.1038/ijo.2017.42. PMid:28190874.

SANTOS, L.S., CORDEIRO, G.S., PEREZ, G.S., SANTO, D.A.E., MACÊDO, A.P.A., LIMA, M.S., CARNEIRO, I.B.C., MACHADO, M.E.P.C., DEIRÓ, T.C.B.J. and BARRETO-MEDEIROS, J.M., 2019. Influence of mother nutrition during pregnancy and/or lactation on offspring food preference in experimental models. Brazilian Journal of Biology $=$ Revista Brasileira de Biologia, vol. 79, no. 2, pp. 220-232. http://dx.doi.org/10.1590/15196984.179134. PMid:30156603.

SIQUEIRA, A.L. and TIBÚRCIO, J.D. 2011, Estatística na área da saúde: conceitos, metodologia, aplicações e prática computacional. Belo Horizonte, MG: Coopmed.

SOSPEDRA, I., MORAL, R., ESCRICH, R., SOLANAS, M., VELA, E. and ESCRICH, E., 2015. Effect of high fat diets on body mass, Oleylethanolamide plasma levels and oxytocin expression in growing rats. Journal of Food Science, vol. 80, no. 6, pp. H1425-H1431. http://dx.doi.org/10.1111/1750-3841.12890. PMid:25976631.

SOUZA, R.M., SOUZA, L., MACHADO, A.E., DE BEM ALVES, A.C., RODRIGUES, F.S., AGUIAR JUNIOR, A.S., SANTOS, A.R.S., DE BEM, A.F. and MOREIRA, E.L.G., 2018. Behavioural, metabolic and neurochemical effects of environmental enrichment in high-fat cholesterol-enriched diet-fed mice. Behavioural Brain Research, vol. 359, pp. 648-656. http://dx.doi.org/10.1016/j. bbr.2018.09.022. PMid:30287273.

TARDIF, N., SALLES, J., GUILLET, C., TORDJMAN, J., REGGIO, S., LANDRIER, J.F., GIRAUDET, C., PATRAC, V., BERTRAND-MICHEL, J., MIGNE, C., COLLIN, M.L., CHARDIGNY, J.M., BOIRIE, Y. and WALRAND, S., 2014. Muscle ectopic fat deposition contributes to anabolic resistance in obese sarcopenic old rats through eIF $2 \alpha$ activation. Aging Cell, vol. 13, no. 6, pp. 1001-1011. http://dx.doi.org/10.1111/ acel.12263. PMid:25139155.

WEST, D. B. and YORK, B., 1998. Dietary fat, genetic predisposition, and obesity: Lessons from animal models. The American journal of clinical nutrition, vol. 67 , no. 3, pp. 505S-512S. https://doi. org/10.1093/ajcn/67.3.505S 